\section{Demography and health of the Xavante Indians of Central Brazil}

\author{
Demografia e saúde do povo indígena Xavante de \\ Mato Grosso, Brasil
}

\begin{abstract}
This study investigates the demographic and health behavior of the Xavante Indians of Mato Grosso State, Central Brazil. Data covering the period 1999 to 2004 was collected using information from household censuses and vital statistics. In addition to standard demographic analyses, survival analysis was carried out. Results show a young age structure, derived from a combination of high fertility rates (7.7 live births per woman) and declining mortality. Mortality rates, especially infant mortality (97 per thousand), remain very high, surpassing regional and national rates. Natural increase is the main contributing factor to population growth. The annual population growth rate is $4.4 \%$. Results suggest that recent declines in mortality and fertility may be related to transformations in the implementation of basic health care services and internal diversity, the latter of which seems to be associated with local history and sociocultural determinants.
\end{abstract}

Demography; Fertility; Mortality; Survival Analysis; South American Indians
Luciene Guimarães de Souza 1 Ricardo Ventura Santos 2,3 Heloisa Pagliaro + Marilia Sá Carvalho 2 Nancy May Flowers 4 Carlos E. A. Coimbra Jr. ${ }^{2}$

\section{Introduction}

It is estimated that the countries of Latin America have approximately 400 different indigenous ethnic societies, with a total population of around 50 million 1. Of these countries, Brazil has one of the smallest indigenous populations compared to total population, since indigenous people make up only $0.5 \%$ of its population. Although the indigenous population is such a small proportion of the total, more than half of all indigenous ethnic groups in Latin America are located in Brazil: there are around 220 distinct peoples, speaking some 180 different languages 2 .

Until very recently, even in the 1970s, a common prognosis for indigenous peoples in Brazil was that, with the inevitable assimilation into national society, they were destined to disappear as culturally differentiated societies 3,4 . In recent years an increasing number of demographic studies of indigenous peoples have been carried out in Brazil 4 as well as in other Latin American countries ${ }^{5}$. One of the most salient demographic trends documented in these studies is the rapid population growth of some indigenous groups 5 .

A growing body of evidence shows that health indicators for indigenous peoples tend to be worse than those of non-Indians 6,7. For instance, data from the 2000 Demographic Census indicate that the infant mortality of indigenous peoples is higher than that of all other color or race groups in Brazil, exceeding even that of blacks ${ }^{8}$. More 
recently, results from the First National Survey on Indigenous Nutrition and Health have shown that the prevalence of anemia and undernutrition in indigenous children is much higher than in nonIndian children ${ }^{9}$. Much research is still needed to understand the complex social determinants of indigenous health, which include, among other factors, transformations in subsistence practices, social and political configurations, access to land, and health care 10.

The objective of this study is to investigate the demographic characteristics of the Xavante, one of the most numerous indigenous peoples of Brazil, whose territory lies in the central region of the country, in the state of Mato Grosso. Although a number of studies have been published about Xavante demographics, all are based on specific villages (see review in Coimbra Jr. et al. ${ }^{11}$ ). The present study is the first to analyze the demography of the Xavante people as a whole. We analyze the demographic characteristics of the Xavante, especially in relation to health, taking into account their recent history, dominated by economic processes that involve relations with non-Indians. Our research also found evidence that leads us to argue that the new health care system for indigenous peoples, which was implemented by the Brazilian government in 1999, is affecting child survival, length of birth intervals, and in consequence, women's fertility.

\section{Population and methods}

\section{The Xavante}

Although the Xavante are divided into politically autonomous groups, they are a single ethnic group in the sense that they share a language, as well as customs and institutions that distinguish them from other neighboring peoples $11,12,13,14,15$

The Xavante presently occupy seven reservations in the eastern part of Mato Grosso. Each reservation has a different history of contact with the outside society, but the land around all of them is occupied by cattle ranches, industrial farms, smallholdings, roads, missions, and towns $11,12,13,14,15$

In the 1940s, the Brazilian government was deeply engaged in the effort to populate its central region, seen as "wilderness", and open it to economic integration with the rest of the country 11,16. Direct state intervention consisted in large part of road building and carrying out the enormous enterprise of building Brasília, the new national capital. As a result of the thrust of settlement and development during the 1950s and 1960s a number of Xavante groups were driven from their lands. By the end of the 1950s they were reduced to small patches of population 14 .

During the same decades the Xavante suffered from epidemic diseases that severely reduced their population. In the 1970s the Xavante began to reassert their land claims with vigor, seeking to recover possession of at least a portion of their traditional territory. Since this time Xavante lives have become increasingly structured by interaction with Brazilian society and by political and economic events that occur beyond the reservations 17 .

Toward the end of the 1970s the National Indian Foundation (FUNAI), a government agency, introduced a project aimed at making the Xavante large-scale rice producers 18 . The scheme failed, but it left a trail of dependence on rice monoculture and resulting changes in food habits.

In recent decades, there has been a decline in subsistence agriculture and a great increase in economic dependence. Store-bought foods acquired in neighboring towns are increasingly included in the Xavante diet. They purchase these foods with money from wage labor, and from government pensions, which have become important sources of income.

The Subsystem for Indigenous Health Care was instituted in Brazil in 1999, under the coordination of the National Health Foundation (FUNASA) 19. This special health service for indigenous peoples was instituted and structured according to geographical districts entitled Special Indigenous Health Districts, or DSEI, which are linked to the National Health Service (SUS). The Xavante district, one of the 34 Indigenous Health Districts in Brazil, is located in Barra do Garças, Mato Grosso.

\section{Data sources and analysis}

The demographic data on which this study is based are descriptive and cross-sectional, covering the period from 1999 to 2004. They are derived from two main sources: household censuses and records of vital statistics. The instrument used for the household censuses is the Indigenous Family Survey, carried out by FUNASA. This survey was first carried out in 1999 and 2000, when the new indigenous health care system was implemented. Data from this survey provided basic demographic information for the Health Services Information System (SIASI) of FUNASA. The forms have been updated at least once a year, providing a continuous flow of information about births and deaths, marriages, household composition, and migration. The censuses are carried out and updated by the 
health teams of the DSEI Xavante that work in the villages and in the Indian health clinics (Casas do Índio).

Vital statistics (births and deaths) are also derived from the monthly reports that are sent to the office of the DSEI Xavante by the health professionals who visit the villages on a regular basis and by those who staff the Indian health clinics.

During the period covered by this paper all the service reports went directly to one of the authors (LGS), who at the time was responsible for organizing and evaluating the reports. She provided reports to the SIASI, and at the same time drew up spreadsheets where she kept more detailed information including live births, stillbirths, fetal deaths, deaths, and dates of death.

Before the DSEI Xavante initiated operations in 1999, FUNASA health teams attended people on the Sangradouro-Volta Grande, Marechal Rondon and São Marcos reservations. From 1993 on these teams also collected demographic information. LGS also gathered this information, complemented by records from the Salesian missionaries at Sangradouro-Volta Grande and São Marcos, which contained the name, sex, birth date, and marital status of each family member. The Salesians maintained parochial records from the mid-1950s until 1999.

Complementary sources of data were death certificates, usually of patients interned in hospitals within the DSEI Xavante.

After the data were organized we made a preliminary analysis to check the data. The purpose of this procedure was to detect possible inconsistencies and contradictions, such as duplication of information.

Overestimation of the ages of individuals over 50 was a particularly thorny problem, especially for those living at Parabubure. We used women's reproductive period as an age marker; that is, we corrected the record of a women who was recorded as bearing a child between 1999 and 2004, but who was registered with an age of 49 or older. To make the correction we used the birth date of the woman's last child, and calculated that the mother was actually between the ages of 45 and 49 at the time of that birth. When the ages of a woman's children did not permit this correction, we let the woman's existing birth record stand. Whenever possible, using our new estimate of a woman's age, we corrected the overestimated age of her husband, based on ethnographic studies that have shown men to be, on the average, 10 years older than their wives.

For geographic categories we used reservations and the Xavante Health District, to which all of the reservations belong. We defined age cohorts as: under one year, one to four years, then five-year cohorts up to 79, and finally 80 and older. We standardized population numbers as of the $31^{\text {st }}$ of December of each year. To standardize the crude death rate we used the total Xavante population as of 2004 .

In measuring migration we counted immigrations and emigrations, including those between Xavante reservations, but only when a change of residence of at least 12 months was involved. Moves between villages on the same reservation were not counted.

The population of the Marãiwatsede reservation was combined with the population of Pimentel Barbosa for the second three-year period. But for the analyses of migration and of increase in number of villages we considered Marãiwatsede separately.

\section{Statistical methods related to survival analysis}

Birth intervals were analyzed using extended Cox proportional hazards model extension 20. A robust standard error was estimated to correct for multiple events, which in our case were the multiple periods between pregnancies. In order to estimate the number of days between successive pregnancies, we subtracted 280 days (equivalent to 40 weeks) from the date of the second delivery. Cases in which the number of days between the two deliveries were less than 280 days were eliminated from the dataset, since they were not considered biologically plausible.

The following independent variables were considered: whether preceding child was dead or alive, sex of preceding child, period of subsequent delivery (1998 to 2001 or 2002-2004), age of mother at subsequent delivery, and type of marriage at time of subsequent delivery (monogamous or polygynous). We included in the multivariate model variables that were significant to the level of 0.1 using Kaplan-Meier survival analysis. The log-rank test was used to test the equality of the survival functions by weighting their respective time points. To allow for nonlinear effect, the year of delivery was included in the models using a smoothing spline term. The variable age of the mother was tested for nonlinearity and accepted as linear. All survival models were fitted with the statistical software R 21 (R Development Core Team 2010), using the survival package. 


\section{Results}

\section{Population changes}

Between 1999 and 2004 the total Xavante population grew from 9,642 to 11,988 . This amounts to a mean annual growth rate of $4.4 \%$. During the same period the number of Xavante villages increased from 98 to 160 (Table 1).

The largest population is that of the Parabubure reservation. In 2004 it had 80 villages and 4,795 inhabitants, representing $40 \%$ of the total Xavante population. São Marcos is another reservation with a large population $(2,566$ inhabitants), representing $21.4 \%$ of the Xavante total population.

The largest annual population growth rate was that of Pimentel Barbosa reservation (5.2\%), closely followed by Parabubure, Areões and Marechal Rondon. The smallest annual growth rate was that of São Marcos and SangradouroVolta Grande (3.9\%) (Table 1).

The greatest increase in number of villages was on Parabubure, Sangradouro-Volta Grande and São Marcos, with respectively 25, 16, and 12 new villages over six years. Only Pimentel Barbosa had no new villages (Table 1). Natural increase, the difference between births and deaths, has been the main factor in the growth of the Xavante population, since external migration, that is, entering a reservation from or leaving a reservation to a non-Xavante area, is practically irrelevant.

\section{Age composition}

Xavante population pyramids are typical of very young populations where birth and death rates are high, resulting in rapid natural increase (Figure 1). The wide base of the pyramids shows that, in the different reservations, approximately $40 \%$ of the population is less than five years of age.

Table 2 presents the proportional distribution of the total population and of the different reservations according to three major age groups in 1999-2001 and in 2002-2004. It confirms the exceptionally young age structure of the Xavante population. Between the first and second time period the under 15 portion of the total population remained stable at approximately $53 \%$, as did the over 50 age group at around $7 \%$. The largest percentage under 15 is at the Pimentel Barbosa reservation (approximately 56 percent) and the smallest at Marechal Rondon (approximately $50 \%$ ). The median age in all reservations ranges from 12 to 14 years.

\section{Birthrates and fertility}

Xavante girls are usually married by the time they are 11 or 12 . Boys marry at the end of a period of initiation that begins when they are about 12 years old and lasts for approximately five years. As a result Xavante women have a long reproductive period $12,13,14,15$.

Table 1

Xavante reserves showing size in hectares, population and number of villages in 1999 and 2004, increase in number of villages and mean annual population growth over the two periods.

\begin{tabular}{|c|c|c|c|c|c|c|c|c|}
\hline \multirow[t]{2}{*}{ Reserve (size in hectares) } & \multicolumn{3}{|c|}{1999} & \multicolumn{3}{|c|}{2004} & \multicolumn{2}{|c|}{ 1999-2004 } \\
\hline & $\begin{array}{l}\text { Number of } \\
\text { villages }\end{array}$ & $\begin{array}{l}\text { Popula- } \\
\text { tion }\end{array}$ & $\begin{array}{l}\text { Proportion of } \\
\text { total popula- } \\
\text { tion (\%) }\end{array}$ & $\begin{array}{l}\text { Number } \\
\text { of villages }\end{array}$ & $\begin{array}{l}\text { Popu- } \\
\text { lation }\end{array}$ & $\begin{array}{l}\text { Proportion of } \\
\text { total popula- } \\
\text { tion (\%) }\end{array}$ & $\begin{array}{l}\text { Increase in } \\
\text { number of } \\
\text { villages }\end{array}$ & $\begin{array}{c}\text { Mean annual } \\
\text { population } \\
\text { growth rate }\end{array}$ \\
\hline Parabubure $(224,447)$ & 55 & 3,857 & 40.0 & 80 & 4,795 & 40.0 & 25 & 4.6 \\
\hline São Marcos $(188,478)$ & 14 & 2,138 & 22.2 & 26 & 2,566 & 21.4 & 12 & 3.9 \\
\hline Pimentel Barbosa $(328,966)$ & 5 & 1,297 & 13.5 & 5 & 1,446 & 12.1 & - & 5.2 \\
\hline $\begin{array}{l}\text { Sangradouro-Volta Grande } \\
(100,280)\end{array}$ & 9 & 1,033 & 10.7 & 25 & 1,256 & 10.5 & 16 & 3.9 \\
\hline Areões (218.515) & 11 & 890 & 9.2 & 15 & 1,093 & 9.1 & 4 & 4.4 \\
\hline Marechal Rondon $(98,500)$ & 4 & 427 & 4.4 & 8 & 520 & 4.4 & 4 & 4.2 \\
\hline Marãiwatsede $(168,000)$ & - & - & - & 1 & 312 & 2.6 & 1 & - \\
\hline Total & 98 & 9,642 & 100.0 & 160 & 11,988 & 100.0 & 62 & 4.4 \\
\hline
\end{tabular}

Note: according to the National Indian Foundation (Fundação Nacional do Índio - FUNAl) 38, 11 Xavante Reserves are recognized. However, the indigenous lands Areões I, Areões II, Chão Preto, Marãiwátsede and Ubawawe are still occupied by squatters and a court decision is awaited as to the status of these lands. With the exception of Marãiwátsede, all of these areas are contiguous with existing official reserves. 
Figure 1

Xavante age-sex population pyramids for each reserve in 2004.

1a) Areões, 2004

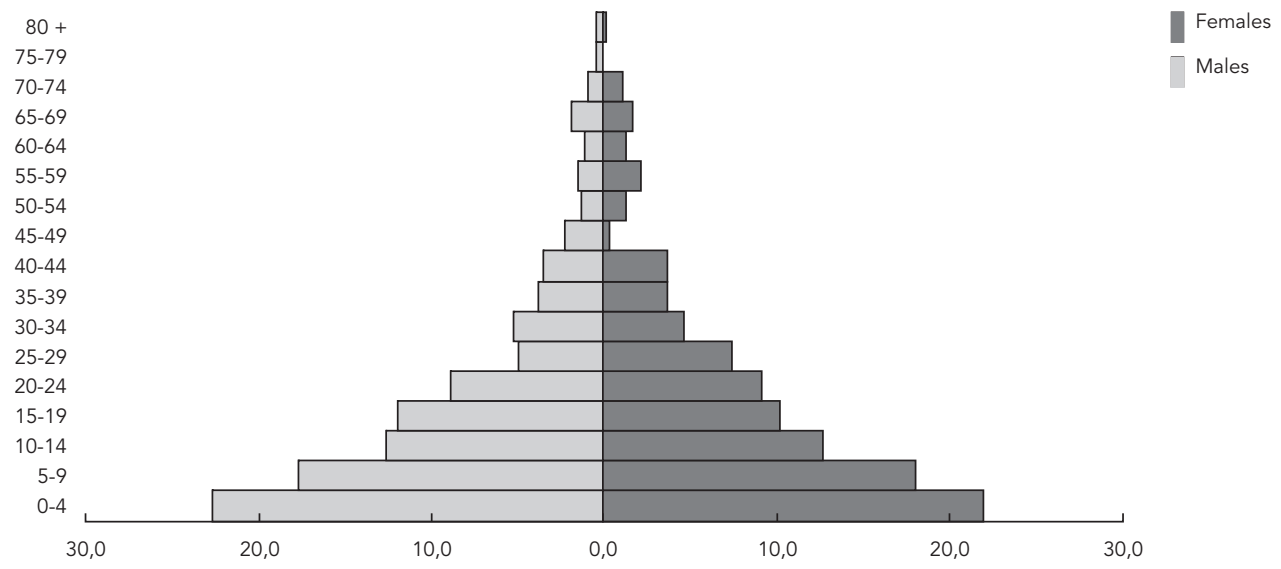

1b) Pimentel Barbosa, 2004

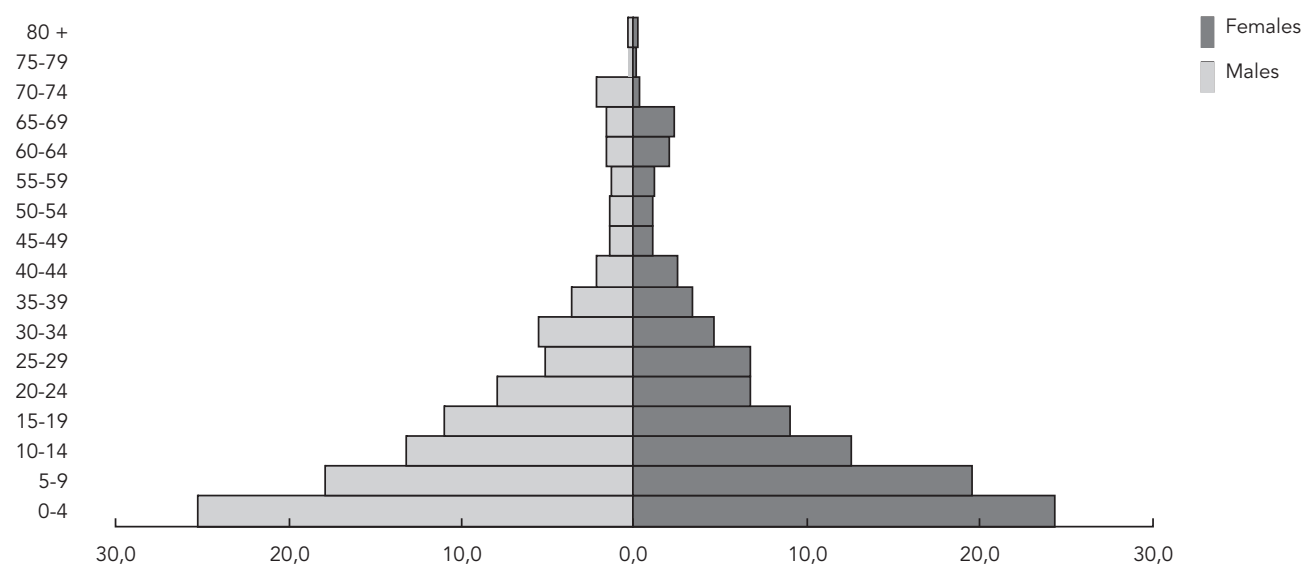

1c) Marechal Rondon, 2004

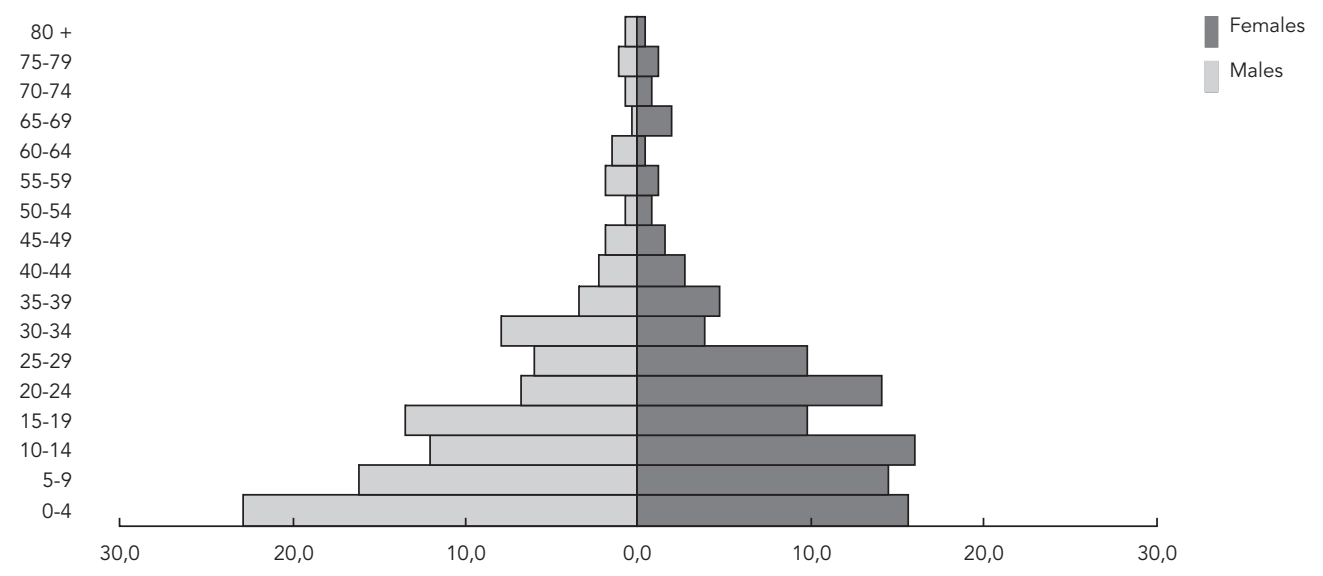


1d) Sangradouro-Volta Grande, 2004

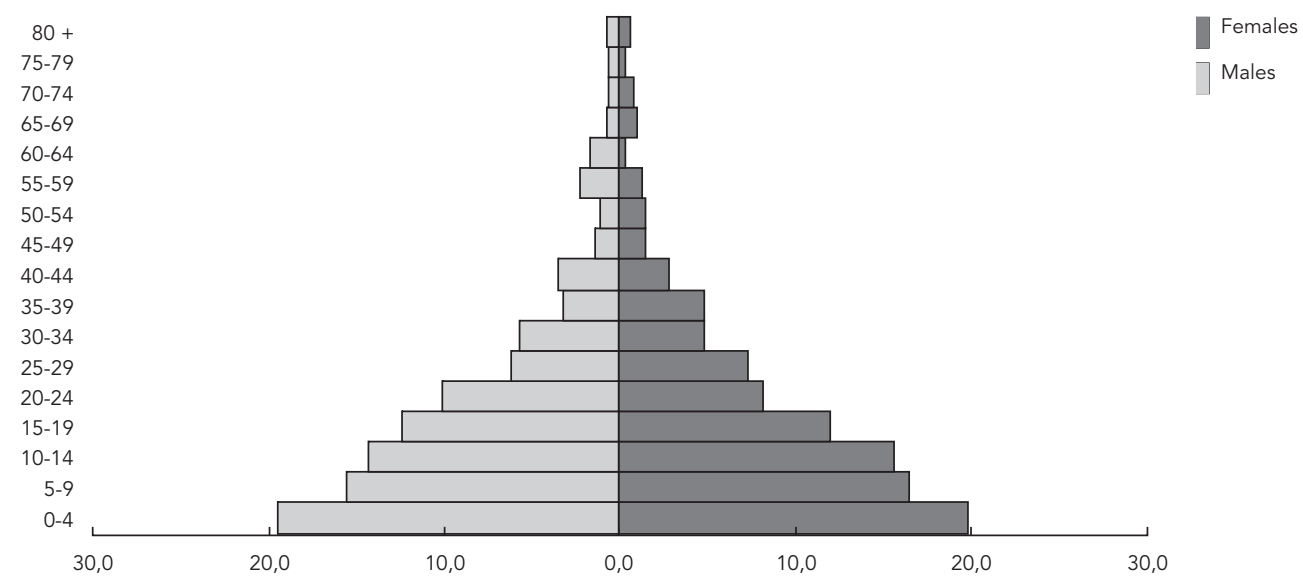

1e) São Marcos, 2004

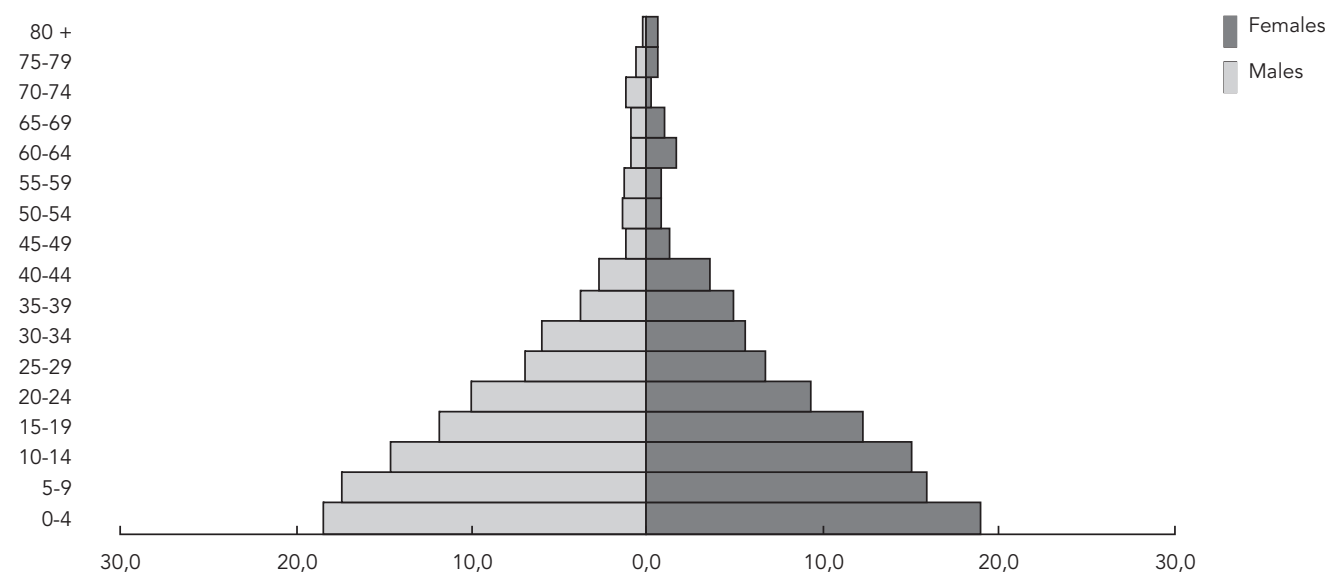

1f) Parabubure, 2004

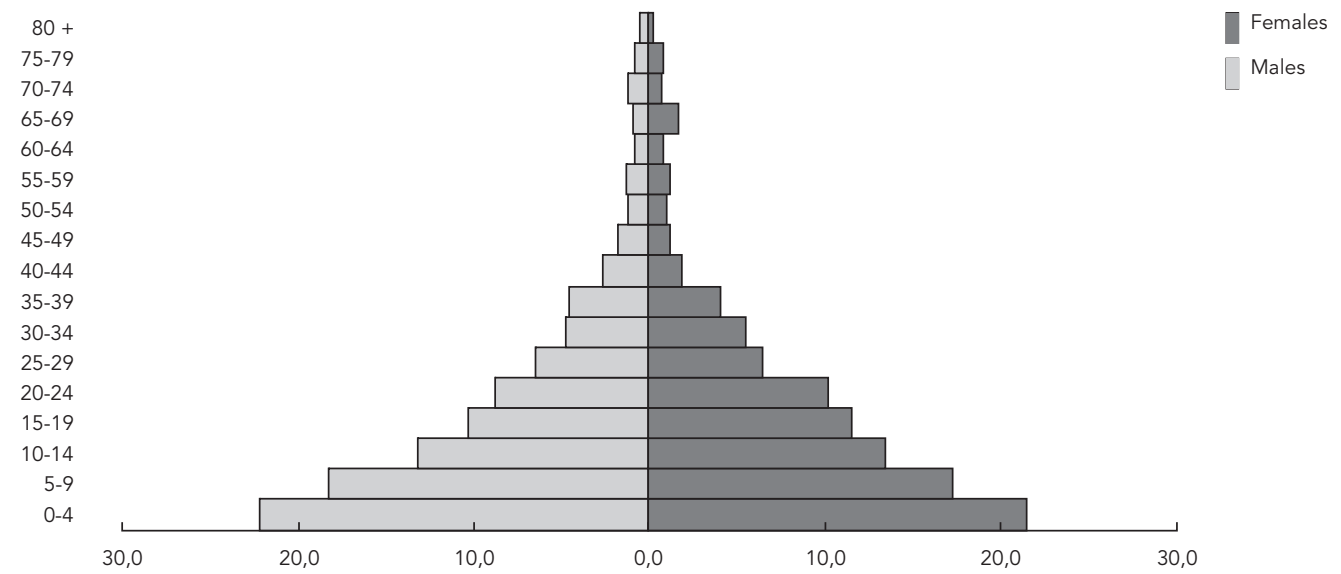


Proportion of Xavante population (\%) by age group in the periods 1999 to 2001 and 2002 to 2004.

\begin{tabular}{|c|c|c|c|c|c|c|c|c|c|c|c|c|c|c|}
\hline \multirow{2}{*}{$\begin{array}{l}\text { Age } \\
\text { group } \\
\text { (years) }\end{array}$} & \multicolumn{2}{|c|}{ Parabubure } & \multicolumn{2}{|c|}{ São Marcos } & \multicolumn{2}{|c|}{ Pimentel Barbosa } & \multicolumn{2}{|c|}{$\begin{array}{l}\text { Sangradouro- } \\
\text { Volta Grande }\end{array}$} & \multicolumn{2}{|c|}{ Areões } & \multicolumn{2}{|c|}{ Marechal Rondon } & \multicolumn{2}{|c|}{ Total } \\
\hline & $\begin{array}{l}1999- \\
2001\end{array}$ & $\begin{array}{l}2002- \\
2004\end{array}$ & $\begin{array}{l}1999- \\
2001\end{array}$ & $\begin{array}{l}2002- \\
2004\end{array}$ & $\begin{array}{l}1999- \\
2001\end{array}$ & $\begin{array}{l}2002- \\
2004\end{array}$ & $\begin{array}{l}1999- \\
2001\end{array}$ & $\begin{array}{l}2002- \\
2004\end{array}$ & $\begin{array}{l}1999- \\
2001\end{array}$ & $\begin{array}{l}2002- \\
2004\end{array}$ & $\begin{array}{l}1999- \\
2001\end{array}$ & $\begin{array}{l}2002- \\
2004\end{array}$ & $\begin{array}{l}1999- \\
2001\end{array}$ & $\begin{array}{l}2002- \\
2004\end{array}$ \\
\hline $0-14$ & 53.7 & 53.4 & 53.4 & 51.4 & 56.2 & 56.4 & 53.8 & 51.7 & 53.4 & 52.7 & 51.1 & 49.9 & 53.8 & 53.0 \\
\hline $15-49$ & 38.8 & 39.8 & 40.1 & 42.2 & 34.2 & 35.1 & 38.7 & 41.0 & 37.9 & 39.4 & 41.0 & 42.8 & 38.4 & 39.9 \\
\hline $\begin{array}{l}50 \text { and } \\
\text { above }\end{array}$ & 7.6 & 6.8 & 6.6 & 6.4 & 9.6 & 8.5 & 7.6 & 7.3 & 8.7 & 7.9 & 7.9 & 7.3 & 7.7 & 7.1 \\
\hline Total & 100.0 & 100.0 & 100.0 & 100.0 & 100.0 & 100.0 & 100.0 & 100.0 & 100.0 & 100.0 & 100.0 & 100.0 & 1000 & 100.0 \\
\hline
\end{tabular}

Note: the population of the Pimentel Barbosa reserve includes the population numbers of the Marãiwatsede Reserve in 2004.

The estimated crude birth rate of the Xavante population as a whole in the period from 1999 to 2004 was 59.2 births per thousand inhabitants. Even when taking into consideration the random fluctuation of small numbers when calculated in three-year periods, a comparison of the earlier with the later period shows a real tendency for the birthrate of the total population to decline, as it fell nearly $6 \%$ from 61.2 births per thousand in 1999-2001 to 57.3 births per thousand in 2002-2004 (Table 3). This decline in the overall birthrate is consistent throughout the reservations. On São Marcos and Marechal Rondon, the decline was over $20 \%$.

When calculated as a mean of the years from 1999 to 2004, the highest birthrates were recorded in Pimentel Barbosa, Parabubure and Areões, nearly 60 per thousand. Marechal Rondon, Sangradouro-Volta Grande and São Marcos had the lowest birthrates, around 50 per thousand.

Changes in the fertility of Xavante women can be seen by comparing the total fertility rates (TFRs) for the 1999-2001 period with those of 2002-2004. Total fertility rate is a statistic that represents the level or intensity of fertility as the average number of liveborn children born to each woman during her reproductive years (Table 4). The mean total fertility rate in the 1999-2004 period was 7.7 live births per woman. Despite the high fertility levels, during this same time period the total fertility rate declined by 1.4 children, on the average, per woman.

Looking at the different reservations, the highest mean TFR (10.1) in the 1999-2004 period was at Pimentel Barbosa, and the lowest at Marechal Rondon (6.2). With the exception of Pimentel Barbosa, the reservations showed a decline in fertility from the first to the second threeyear period. The greatest change was at Marechal Rondon, where women during the 2002-2004 pe- riod had, on the average, 2.8 fewer children than in 1999-2001.

The fertility of Xavante women can be understood better by analyzing age specific fertility rates, which indicate the age pattern of this demographic component.

Age-specific fertility rates (ASFR) for Xavante women as a whole for the 1999-2001 and the 2002-2004 periods are compared in Figure 2. In both periods the age structure of fertility is typically young. We see a decline in fertility for all age cohorts.

\section{Mortality}

The annual crude death rate for the Xavante population as a whole varied between 12.7 and 11.4 deaths per thousand during the period from 1999 to 2004 , with an observed mean of 12.1 deaths per thousand (Table 5). Mortality rates varied considerably between the reservations: the highest rate, 13.5 per thousand, was at Areões, and the lowest, 7.4 per thousand, at Marechal Rondon.

The mean infant mortality rate for the total Xavante population for the 1999-2004 period was 96.7 per thousand. The rate showed a tendency to decline, falling nearly $15 \%$ from 103.3 deaths per thousand in 1999-2001 to 89.8 per thousand in 2002-2004.

Looking at infant mortality rates during the 1999-2004 period by reservation, we found that they varied considerably, with a $42.5 \%$ difference between the highest at São Marcos (129.5) and the lowest (74.4) at Sangradouro-Volta Grande (Table 6). 
Crude birth rates in Xavante reserves showing relative variation for the period 1999 to 2004.

\begin{tabular}{lcccc}
\hline Reserve & $\mathbf{1 9 9 9}$ to $\mathbf{2 0 0 1}$ & $\mathbf{2 0 0 2}$ to2004 & Relative variation (\%) & $\mathbf{1 9 9 9}$ to 2004 \\
\hline Parabubure & 64.1 & 52.7 & -17.8 & 58.1 \\
São Marcos & 58.3 & 45.1 & -22.6 & 51.4 \\
Pimentel Barbosa & 67.3 & 60.3 & -10.4 & 63.5 \\
Sangradouro-Volta Grande & 52.6 & 46.1 & -12.4 & 49.1 \\
Areões & 58.9 & 56.7 & -3.7 & 57.7 \\
Marechal Rondon & 56.4 & 42.1 & -25.4 & 48.8 \\
Total & 61.2 & 57.3 & -6.4 & 59.2 \\
\hline
\end{tabular}

Note: the population of the Pimentel Barbosa reserve includes the population numbers of the Marãiwatsede Reserve in 2004.

Table 4

Total fertility rates (TFRs) and weighted TFRs for Xavante women in the periods 1999 to 2001 and 2002 to 2004 .

\begin{tabular}{lccc}
\hline Reserve & 1999 to 2001 & 2002 to 2004 & Total \\
\hline Parabubure & 8.8 & 7.4 & 8.0 \\
São Marcos & 8.1 & 6.1 & 7.0 \\
Pimentel Barbosa & 10.3 & 9.9 & 10.1 \\
Sangradouro-Volta Grande & 7.8 & 6.1 & 6.8 \\
Areões & 7.9 & 7.5 & 7.6 \\
Marechal Rondon & 7.7 & 4.9 & 6.2 \\
Total & 8.5 & 7.1 & 7.7
\end{tabular}

Note: the population of the Pimentel Barbosa reserve includes the population numbers of the Marãiwatsede Reserve in 2004.

\section{Relationship between birth intervals and selected variables}

Kaplan-Meier graphics, including the p-value associated with each independent variable related to the length of the birth intervals, are presented in Figure 3. In the first frame it may be observed that the death of a preceding child tends to result in a birth interval decrease, although the significance is borderline $(p=0.07)$. The second frame compares the two time periods, showing that in the later (2002-2004) birth intervals are significantly longer. As expected, birth intervals increase with the age of the mother. Finally, type of marriage (monogamous or polygynous) (Frame 4) and sex of the preceding child (not shown) are not associated with length of birth interval.

The fit of the smooth spline term over the time period for which we have data (1998 to 2004) was significant, pointing to a non-linear association with the length of the birth intervals (Figure 4). There is a marked plateau in the time period 1999-2000, coincident with the implementa- tion of the new indigenous health care system in Brazil. The model suggests that, after the year 2000, the trend was toward a marked increase in the length of the birth intervals. The plateau from 1999 to 2000 may reflect the lag time between changes in health practices and their impact on child survival. It should be noted that because the number of observations in 1998 was very small, interpretations based on the first two years of the study period should be treated with caution.

The inclusion of the age of the mother and the status of the preceding child (dead or alive) in the model made the association between calendar year and birth interval linear. For each additional calendar year, the length of birth interval increased by $15 \%$ (HR = 0.857; CI: 0.829-0.885).

The findings presented above show that fertility dropped from 1998-2001 to 2002-2004. Comparing the two time periods using survival analysis, with the first period as reference, for each additional year of the mother's age, the hazard of another birth significantly decreases by close to $3 \%$ (HR = 0.973; CI: 0.967-0.979). If the preceding 
Figure 2

Age-specific fertility rates (ASFRs) of Xavante women for the periods 1999 to 2001 and 2002 to 2004.

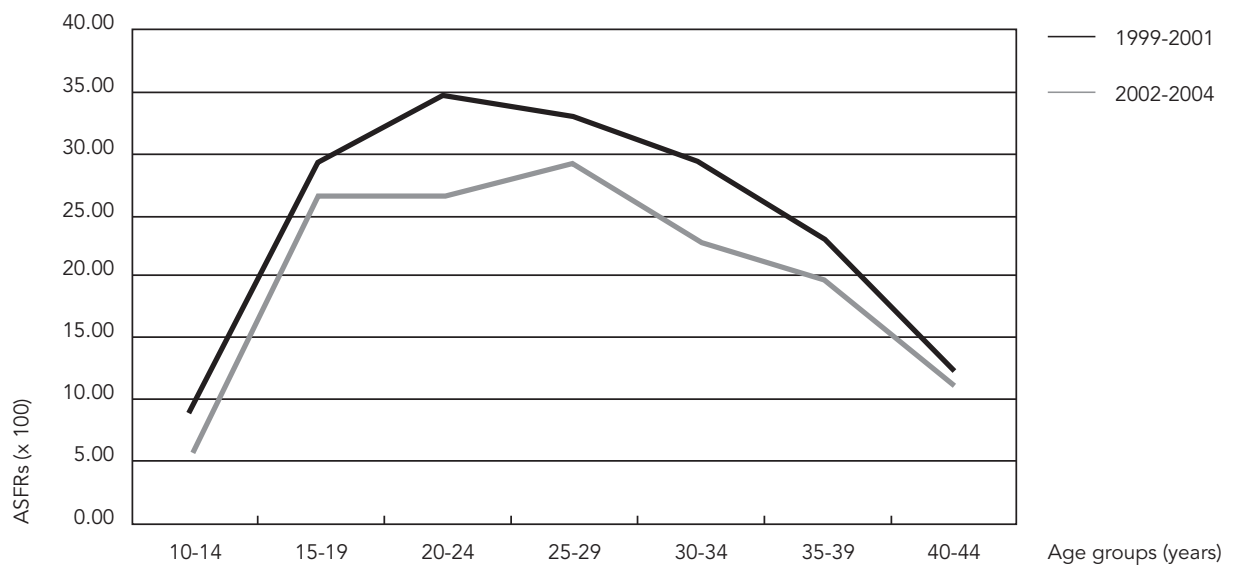

Table 5

Crude death rates per thousand per Reserve in the periods 1999 to 2001 and 2002 to 2004.

\begin{tabular}{|c|c|c|c|c|c|c|}
\hline \multirow[t]{2}{*}{ Reserve } & \multicolumn{2}{|c|}{ Observed } & \multicolumn{2}{|c|}{ Standardized } & \multicolumn{2}{|c|}{1999 to 2004} \\
\hline & 1999 to 2001 & 2002 to 2004 & 1999 to 2001 & 2002 to 2004 & Observed & Standardized \\
\hline Parabubure & 13.6 & 11.7 & 12.3 & 11.0 & 12.6 & 11.6 \\
\hline São Marcos & 12.6 & 13.7 & 12.0 & 14.9 & 13.2 & 13.4 \\
\hline Pimentel Barbosa & 11.7 & 10.0 & 9.8 & 9.2 & 10.7 & 9.4 \\
\hline Sangradouro-Volta Grande & 9.3 & 10.5 & 9.8 & 12.9 & 10.1 & 10.4 \\
\hline Areões & 17.7 & 9.8 & 16.3 & 8.9 & 13.5 & 13.0 \\
\hline Marechal Rondon & 6.0 & 8.0 & 5.4 & 9.6 & 7.4 & 7.4 \\
\hline Total & 12.7 & 11.4 & 9.1 & 11.1 & 12.1 & 11.4 \\
\hline
\end{tabular}

Note: the population of the Pimentel Barbosa reserve includes the population numbers of the Marãiwatsede Reserve in 2004.

Table 6

Infant mortality rates per thousand per Reserve in the periods 1999 to 2001 and 2002 to 2004.

\begin{tabular}{lccc}
\hline Reserve & $\mathbf{1 9 9 9}$ to $\mathbf{2 0 0 1}$ & $\mathbf{2 0 0 2}$ to $\mathbf{2 0 0 4}$ & $\mathbf{1 9 9 9}$ to 2004 \\
\hline Parabubure & 95.4 & 89.4 & 92.5 \\
São Marcos & 123.1 & 136.9 & 129.5 \\
Pimentel Barbosa & 108.7 & 59.0 & 83.3 \\
Sangradouro-Volta Grande & 59.2 & 89.8 & 74.4 \\
Areões & 147.2 & 50.3 & 96.5 \\
Marechal Rondon & 66.7 & 95.2 & 79.7 \\
Total & 103.3 & 89.8 & 96.7 \\
\hline
\end{tabular}

Note: the population of the Pimentel Barbosa reserve includes the population numbers of the Marãiwatsede Reserve in 2004. 
Figure 3

Effect of selected variables on the length of birth intervals in the Xavante derived from survival analyses.

3a) Preceding child dead or alive

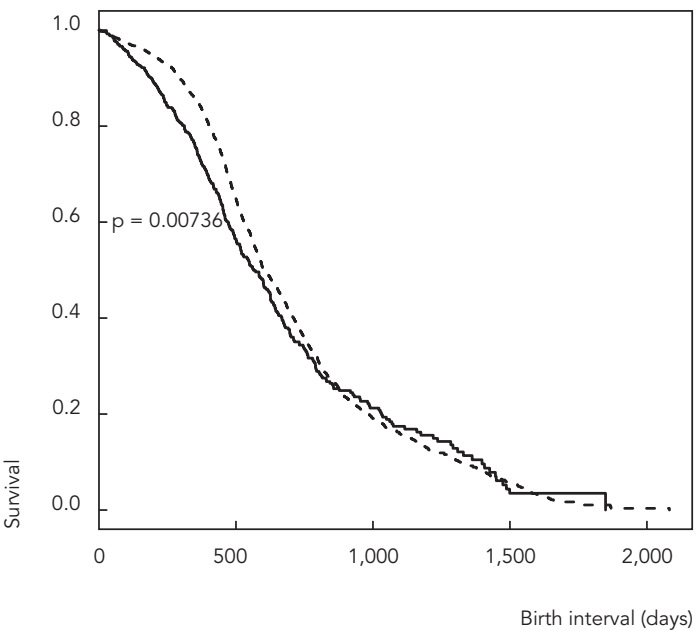

3c) Age of mother

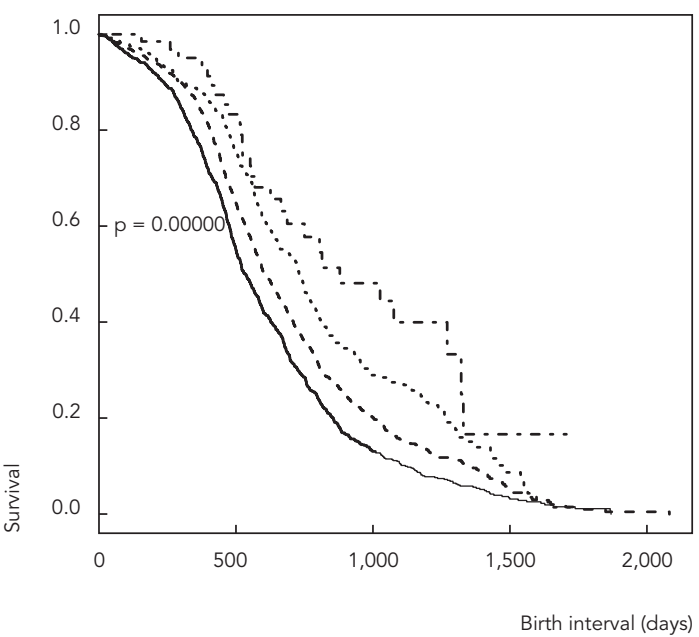

3b) Period of subsequent delivery
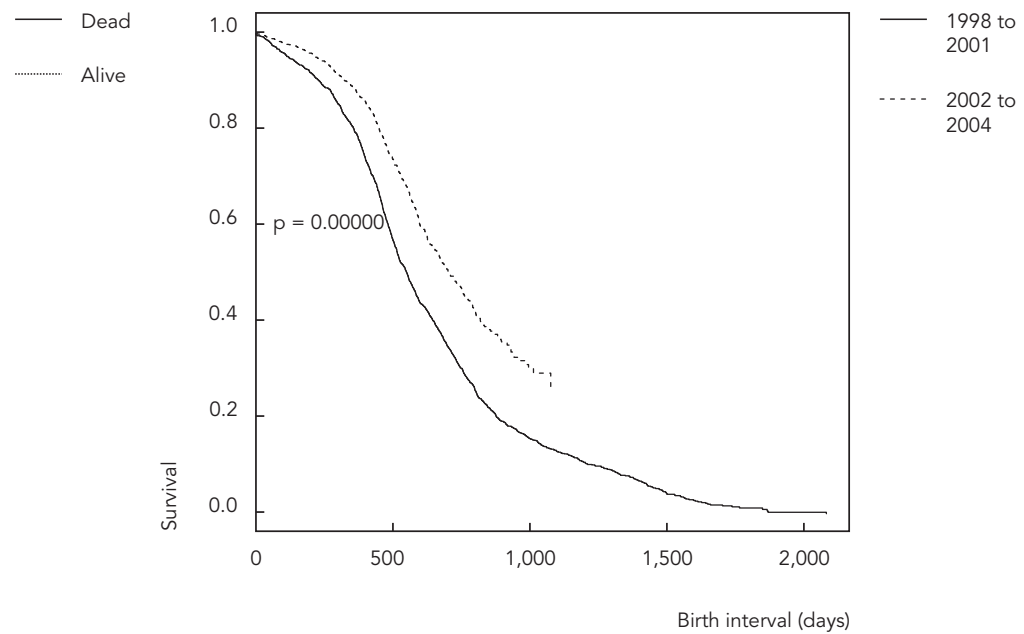

3d) Type of marriage (mono or polygynous)

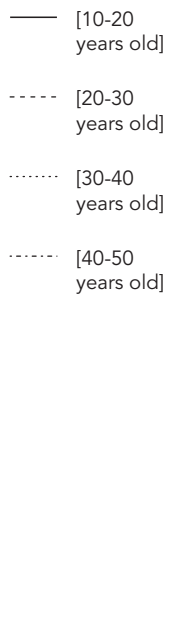

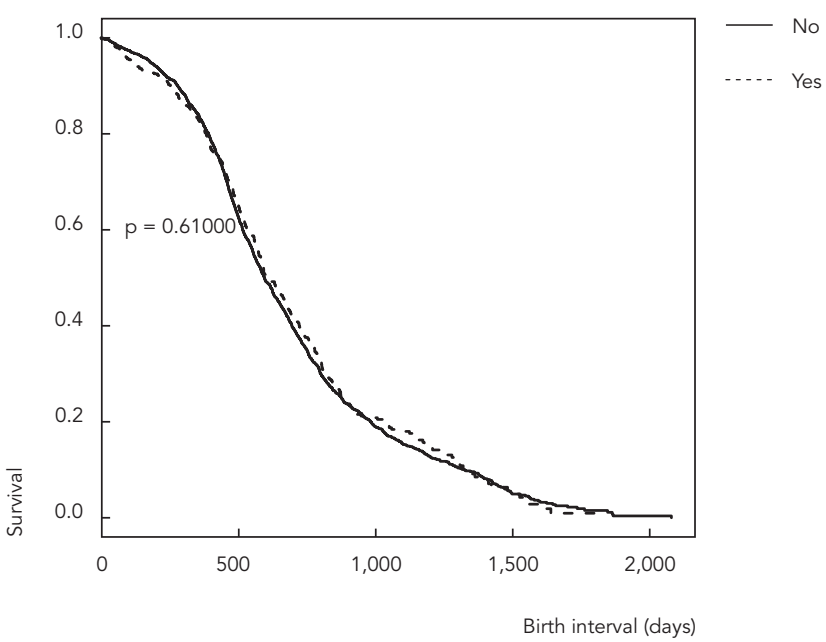

child is alive, the chance of another pregnancy is reduced, although the HR presents borderline significance (HR = 0.891; CI: 0.776-1.024). Finally, the time period variable (1998-2001 and 20022004) showed the largest effect, with the average risk of a new birth decreasing by approximately $30 \%$ between the two periods $(\mathrm{HR}=0.709$; $\mathrm{CI}$ : 0.646-0.778).

\section{Discussion}

Although there has been growing interest since the 1980s among demographers and anthropologists in analyzing the demographic behavior of indigenous peoples in Brazil 4,22,23,24, this field is still under-studied both in Brazil and in other countries of Latin America relative to the great social diversity in the region 1,5 . Demographic in- 


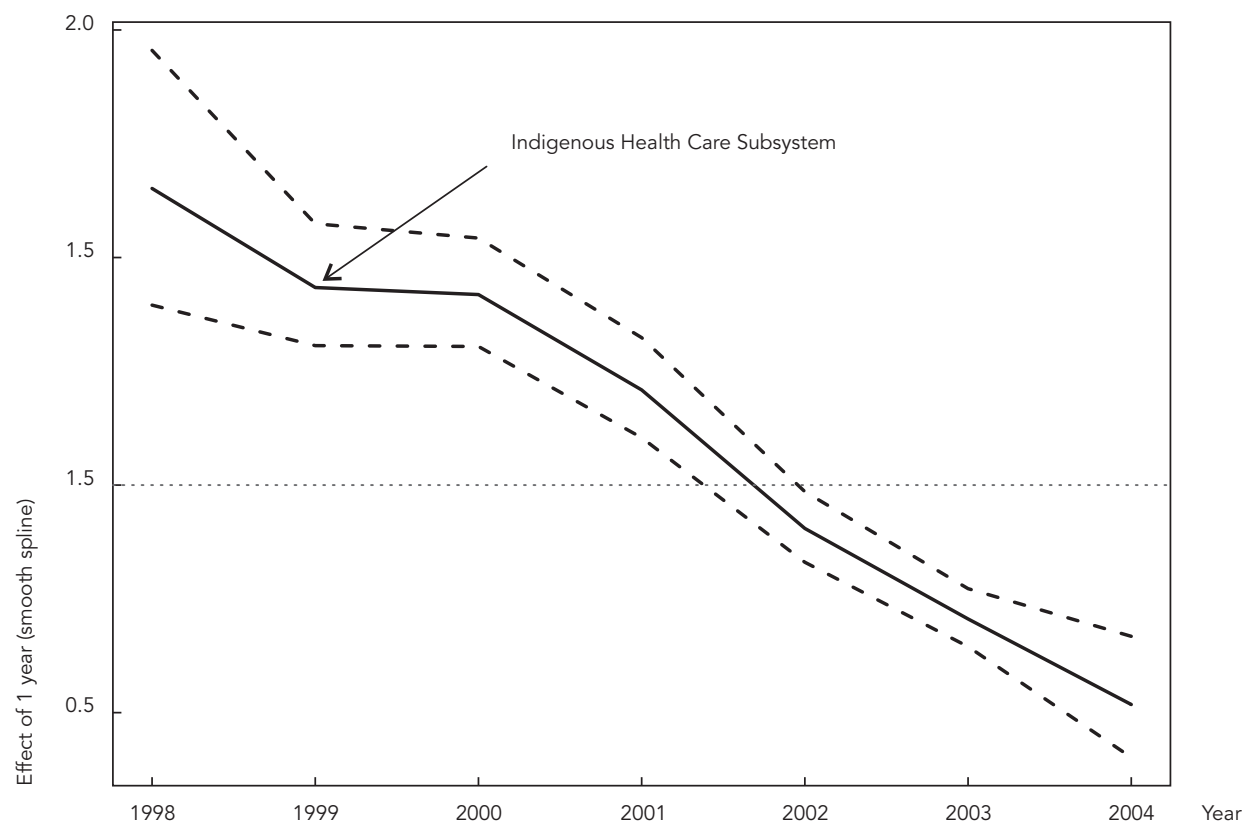

vestigations are of paramount importance since they are highly informative of health disparities.

One of the difficulties of doing demographic research among indigenous peoples is obtaining reliable and complete data. Populations are often small in number and territorially dispersed. It is therefore not surprising that many studies of anthropological demography are based on data from specific communities, seldom considering how representative these may be of the entire ethnic group. Among the few exceptions are the study by Early \& Peters 25 of the Yanomama of Mucajai in the state of Roraima and the participatory socio-demographic investigation among the Sateré-Mawé of the state of Amazonas 24. These studies analyzed the demographic dynamics of relatively large populations that were geographically dispersed. The present study of the Xavante is similar to these.

The overall results show that from 1999 to 2004 the mean annual growth of the Xavante population was $4.4 \%$. The greatest annual growth was at Pimentel Barbosa (5.2\%) and the smallest at São Marcos and Sangradouro-Volta Grande (3.9\%). Population is not evenly distributed among the reservations: Pimentel Barbosa, with more than 300,000 hectares, is the largest reservation, and has the lowest population density, with 0.44 persons per square kilometers. Other areas, like Parabubure and São Marcos, with 2.14 and 1.6 persons per square kilometer respectively, have higher densities than Pimentel Barbosa.

The high population growth rate of the Xavante is similar to those that have been reported for a number of other indigenous peoples in Brazil 4 and in other Latin American countries 5. In Brazil, high growth rates have been reported for the Kaiabi, of the Upper Xingu River, with an annual rate of $5.2 \%$ from 1970 to 1999 4,26; the Macuxi, Taurepangue, Ingarikó, Wapixana, Patamona and Wai-Wai, from eastern Roraima State, with an annual rate of $3.7 \%$ between 2002 and 2004 27; and the Tenetehara of Maranhão (5 percent from 1975 to 1994$)^{28}$. It must be stressed, however, as Pagliaro et al. ${ }^{4}$ point out, that while many indigenous peoples have high demographic growth rates, these cannot be generalized.

From the viewpoint of demography the great challenge, as Azevedo \& Ricardo 29,30 note, is to identify the factors that may explain this increase. In the Xavante case, the figures clearly indicate that natural increase, the difference between births and deaths, is the principal factor responsible for the striking increase in popula- 
tion. Migration is an irrelevant component. Fertility analysis indicates a TFR of 7.7 children per woman, from 1999 to 2004. In a society where marriage and maternity are practically universal, women's reproductive years start in their early teens, peaking at the ages of 20 to 29 . As a result, the population is very young, with $54.0 \%$ under 15 years of age. Xavante population structure and their specific demographic indices are quite similar to those reported for other indigenous peoples with high population growth 4 .

A very important aspect of the Xavante population in both demographic and epidemiological terms is that along with the high growth rate, death rates remain high. The crude death rate for the period from 1999 to 2004 was 12.1 per thousand. Infant mortality was 96.7 per thousand live births. In comparison, the infant mortality rate for all Brazil in 2000 was 29.6 per thousand and for the Center West region it was 21.2 per thousand 31 . These major differences in infant mortality in the Xavante mirror the health disparities that have been shown for indigenous peoples in Brazil compared to non-Indians 6 .

This study is unusual because, while analyzing data for the population as a whole, it also demonstrates considerable variation among Xavante groups in epidemiological and demographic indicators. Differences are evident in practically all measurements analyzed, including birthrates, fertility, migration, and the emergence of new villages. The total fertility rate varied from 6.2 at Marechal Rondon to 10.1 at Pimentel Barbosa; the infant mortality rate varied from 74.4 per thousand at Sangradouro-Volta Grande to 129.5 at São Marcos. The greatest growth in number of new villages was at Parabubure, where 25 new villages were created between 1999 and 2004. On three reservations, Areões, Marechal Rondon e Pimentel Barbosa, four or fewer new villages appeared during the same period.

These internal demographic differences have a number of important implications for social history, epidemiology, and the implementation of public health programs. Some differences between Xavante groups have been described in the ethnological literature. For example, Lopes da Silva 12 (p. 35) divided the Xavante into three major blocks according to the following criteria: a) intensity and characteristics of contact between villages; b) whether or not the group still occupied its traditional territory; c) whether agents of contact were representatives of the state or of the church. The results of the present study do not permit in-depth analysis of the demographic characteristics of different groups. However, recognizing the different trajectories is important in avoiding unjustified generalizations. In terms of public health policy the concept of a subsystem for indigenous health is based on the public health district, defined as, " $a$ model for organizing services, directed toward a space that is well defined in terms of ethnicity, geography, epidemiology, population, and administration" 32 (p. 13). Of the 34 indigenous health districts in the country, there are four that serve only one ethnic group. One is the Xavante; the other three are Potiguara, Kaiapó-Pará and Yanomami. The differences between Xavante sub-groups that we have documented in this study show that, even in single ethnic group districts, it is necessary to be aware of internal variation.

Our study reveals some relevant demographic trends when we divide the period from 1999 to 2004 into two three-year periods: 1999-2001 and 2002-2004. Although the study period is short, when we consider all the reservations together we can observe important changes from the first three-year period to the second: a decline in crude birth rate from 61.2 to 57.3 per thousand, a decline in total fertility rate from 8.5 to 7.1 children per woman, a decline in crude death rate from 12.7 to 10.4 per thousand, and in infant mortality from 103.3 to 89.8 per thousand life births. At the reservation level as well the tendency of almost all these indicators is toward decline, although there is variation, probably due in part to fluctuation in small numbers.

Even though death rates are still high among the Xavante, there has been some decline. Toward the beginning of the period recorded (in 1999) the new Indian health system was implemented. There are indications that, even with the major deficiencies of the current health system, indigenous peoples appear to be obtaining more access to health services, than before 1999 7. Garnelo et al. 33 note in their analysis of the first three years the Indian health system was in effect that national health coverage provided by FUNASA became more inclusive. Lunardi et al. 34 found that there was an increase in the Xavante use of hospital services after 1999. They observed that rates of hospitalization increased for all four reservations analyzed. Despite increased access to hospital services, the major causes of hospitalization in Xavante children remain diarrhea and acute respiratory infections, which indicates that major problems of primary health care are still present at the village level 34 .

While the reduction in Xavante mortality may be associated with the increased investments made in indigenous health in Brazil, the relationship between better health care and the observed decline in natality and fertility is neither obvious nor direct. A possible cause for this reduction might be more access to contraceptive technolo- 
gies; however, in the Xavante case this is probably not the explanation, since health services provided by FUNASA do not include family planning and contraception. This is a politically delicate subject and, although there are no specific studies available on this topic in Brazil, the public position of activists in the indigenous movement is opposed to contraceptives 35 .

One of the most important findings that emerge from this investigation is that the decline in fertility is not the result of directed family planning but appears rather to be a consequence of the reduction in infant mortality due to the implementation of the new indigenous health system. In other words, it may be due to mortality-fertility interaction. Wood 36 argues that, especially in populations with high mortality, fertility levels may be affected more by mortality than by reproduction itself. Wood uses the expression "reproductive compensation". According to him, "when a nursing child dies, lactation is terminated and the mother resumes ovulating sooner than she otherwise would have" 36 (p. 233). Therefore, paradoxically, in a situation where infant mortality is high the total fertility of a group of women may increase. Wood's argument parallels the discussion of the "proximate determinants" of fertility by Bongaarts \& Potter 37, which cites the duration of lactation as an important factor in regulating fertility.

The results of our survival analysis of Xavante birth intervals seem to be consistent with the idea that the reduction of fertility is due to fertility-mortality interaction. A striking finding was a $15 \%$ increase in the average length of time between births for each additional calendar year of the study period. It is also notable that the decline in fertility was spread across all age cohorts, which suggests that the process was general and unfocused. If it were only in the older age brackets we might suspect the use of contraceptives for family limitation. In the short length of time analyzed it is improbable that fertility decline among the Xavante is due to extensive sociocultural change leading to new norms of family size.
A last point to consider is the substantial increase in number of villages and the difference between reservations in the fissioning process. Of the 62 new villages that appeared during the period we analyzed, Parabubure, SangradouroVolta Grande and São Marcos were the reservations with the largest increases: 25, 16, and 12 respectively. Even though Pimentel Barbosa had the highest rate of population increase, 5.2 percent annually, it had the lowest population density, and was the only one that did not add a village.

We may attribute the growth in number of villages to the well-known political factionalism of Xavante society 12 . At present new factors might be stimulating the fission of villages, including population rebound and government policies. For instance, Xavante have been contracted for employment as primary health assistants and sanitation workers at the village level, which stimulates the formation of new communities. Whatever the causes, the constant formation of new villages has become a challenge for policymakers since the installation of new school houses, health posts and basic sanitation infrastructure must be considered when a new village is founded.

In conclusion, this study presents a detailed demographic analysis of the population resident on all seven Xavante reservations based on data gathered over a six-year period. We have documented a demographic pattern characterized by high birthrates resulting in a population with a very young age structure. We also found that mortality rates, and infant mortality in particular, are very high. The continuing high birthrates have resulted in an annual rate of population growth of $4.4 \%$. Our results also suggest that a recent decline in mortality and fertility may be related to transformations in the implementation of basic health care services for indigenous peoples in Brazil. We have also argued that the Xavante present internally demographic diversity, which seems to be associated with local histories and sociocultural determinants. 


\section{Resumo}

Este estudo investiga o comportamento demográfico dos índios Xavante de Mato Grosso, Brasil Central. Os dados foram coletados entre 1999 e 2004, a partir de censos domiciliares e da coleta de estatísticas vitais. Além das análises demográficas, realizou-se análise de sobrevida. Os Xavante apresentam uma estrutura etária jovem, típica de população em fase de recuperação populacional, com alta fecundidade (média de 7,7 nascidos vivos por mulher) e mortalidade em declínio. As taxas de mortalidade, especialmente a infantil (97 por mil), continuam a ser muito elevadas, ultrapassando as taxas regionais e nacionais. O crescimento natural é o principal fator no aumento populacional. A população cresce a uma taxa média de $4,4 \%$ ao ano. Argumenta-se que não somente a recente queda da mortalidade, assim como da fecundidade, podem estar relacionadas à implementação do novo sistema de saúde voltado para os povos indígenas no Brasil a partir de 1999. Os Xavante apresentam significativa diversidade demográfica interna, que parece estar associada a histórias de contato e a determinantes socioculturais.

Demografia; Fecundidade; Mortalidade; Análise de Sobrevida; Índios Sul-Americanos

\section{Contributors}

L. G. Souza, R. V. Santos and H. Pagliaro participated in study conceptualization, data analysis and interpretation, and preparation and revision of the manuscript. C. E. A. Coimbra Jr. and M. S. Carvalho participated in data interpretation and preparation and revision of the manuscript. N. M. Flowers participated in data interpretation and preparation and revision of the manuscript.

\section{Acknowledgments}

We would like to thank CNPq for providing a doctoral fellowship to the first author to study at the National School of Public Health, Oswaldo Cruz Foundation (Escola Nacional de Saúde Pública Sergio Arouca, Fundação Oswaldo Cruz) in Rio de Janeiro, Brazil. Part of this research was sponsored by CNPq (grant $n^{\circ}$. 483483/2007-9). We are also grateful to James Welch for his comments on a preliminary version of this paper.

\section{References}

1. Montenegro RA, Stephens C. Indigenous health. 2 - Indigenous health in Latin America and the Caribbean. Lancet 2006; 367:1859-69.

2. Instituto Socioambiental. Povos indígenas no Brasil - 2001/2005. São Paulo: Instituto Socioambiental; 2006.

3. Gomes MP. O índio na história: o povo Tenetehara em busca da liberdade. Petrópolis: Editora Vozes; 2002.

4. Pagliaro H, Azevedo MM, Santos RV. Demografia dos povos indígenas no Brasil: um panorama crítico. In: Pagliaro H, Azevedo MM, Santos RV, organizadores. Demografia dos povos indígenas no Brasil. Rio de Janeiro: Editora Fiocruz; 2005. p. 11-32.

5. McSweeney K, Arps SA. "Demographic turnaround": the rapid growth of indigenous populations in lowland Latin America. Lat Am Res Rev 2005; 40:3-29.
6. Coimbra Jr. CEA, Santos RV. Emerging health needs and epidemiologic research in indigenous peoples in Brazil. In: Salzano FM, Hurtado M, editors. Lost paradise and the ethics of research and publication. Oxford: Oxford University Press; 2004. p. 89-109.

7. Santos RV, Cardoso AM, Garnelo L, Coimbra Jr. CEA, Chaves MBG. Saúde dos povos indígenas e políticas públicas no Brasil. In: Giovanella L, Escorel S, Lobato L, Noronha JC, Carvalho AI, organizadores. Políticas e sistema de saúde no Brasil. Rio de Janeiro: Editora Fiocruz; 2008. p. 1035-56.

8. Instituto Brasileiro de Geografia e Estatística. Tendências demográficas: uma análise dos indígenas com base nos resultados da amostra dos Censos Demográficos 1991 e 2000. Rio de Janeiro: Instituto Brasileiro de Geografia e Estatística; 2005. 
9. Associação Brasileira de Pós-graduação em Saúde Coletiva. Inquérito nacional de saúde e nutrição dos povos indígenas: relatório final. Rio de Janeiro: Associação Brasileira de Pós-graduação em Saúde Coletiva; 2009.

10. Comissão Nacional sobre Determinantes Sociais de Saúde. As causas sociais das iniqüidades em saúde no Brasil. Rio de Janeiro: Editora Fiocruz; 2008.

11. Coimbra Jr. CEA, Flowers NM, Salzano FM, Santos RV. The Xavante in transition: health, ecology, and bioantropology in Central Brazil. Michigan: University of Michigan Press; 2002.

12. Lopes da Silva A. Nomes e amigos: da prática Xavante a uma reflexão sobre os Jê. São Paulo: Faculdade de Filosofia, Letras e Ciências Humanas, Universidade de São Paulo; 1986.

13. Maybury-Lewis D. Akwê Xavante society. Oxford: Clarendon; 1967.

14. Maybury-Lewis D. A sociedade Xavante. Rio de Janeiro: Editora Francisco Alves; 1984.

15. Flowers NM. Crise e recuperação demográfica: os Xavante de Pimentel Barbosa, Mato Grosso. In: Santos RV, Coimbra Jr. CEA, organizadores. Saúde \& povos indígenas. Rio de Janeiro: Editora Fiocruz; 1994. p. 213-42.

16. Garfield S. The roots of a plant that today is Brazil: Indians and the nation-state under the Brazilian Estado Novo. J Lat Am Stud 1997; 29:747-68.

17. Lopes da Silva A. Dois séculos e meio de história Xavante. In: Cunha MC, organizador. História dos índios no Brasil. São Paulo: Companhia das Letras; 1992. p. 357-78.

18. Menezes CO. Os Xavante e o movimento de fronteira no leste matogrossense. Rev Antropol (São Paulo) 1982; 25:63-87.

19. Fundação Nacional de Saúde. Política de atenção à saúde das populações indígenas. Brasília: Fundação Nacional de Saúde; 2000.

20. Therneau TM., Grambsch PM. Modeling survival data: extending the Cox model. New York: Springer; 2000. (Statistics for Biology and Health).

21. Therneau TM. Survival analysis, including penalized likelihood. R. package version 2.36-5. http:// cran.r-project.org/web/packages/survival/index. html (accessed on 11/Apr/2011).

22. Azevedo MM. Povos indígenas no Alto Rio Negro: um estudo de caso de nupcialidade. In: Pagliaro H, Azevedo MM, Santos RV, organizadores. Demografia dos povos indígenas no Brasil. Rio de Janeiro: Editora Fiocruz; 2005. p. 33-57.

23. Souza LG, Santos RV. Perfil demográfico da população indígena Xavánte de Sangradouro-Volta Grande, Mato Grosso (1993-1997), Brasil. Cad Saúde Pública 2001; 17:355-65.

24. Teixeira P, Brasil M. Estudo demográfico dos Sateré-Mawé: um exemplo de censo participativo. In: Pagliaro H, Azevedo, MM, Santos RV, organizadores. Demografia dos povos indígenas no Brasil. Rio de Janeiro: Editora Fiocruz; 2005. p. 135-54.
25. Early JD, Peters JF. The population dynamics of the Mucajai Yanomama. San Diego: Academic Press; 1990.

26. Pagliaro H. A revolução demográfica dos povos indígenas no Brasil: a experiência dos Kaiabí do Parque Indígena do Xingu, Mato Grosso, Brasil, 1970-2007. Cad Saúde Pública 2010; 26:579-90.

27. Costa I. Mortalidade infantil e alguns indicadores demográficos no DSEI leste de Roraima, 2002-2004 [Dissertação de Mestrado]. Rio de Janeiro: Escola Nacional de Saúde Pública Sérgio Arouca, Fundação Osvaldo Cruz; 2006.

28. Gomes MP. Os índios e o Brasil. Petrópolis: Editora Vozes; 1988.

29. Azevedo MM, Ricardo FP. Indigenous lands and peoples: recognition, growth and sustenance. In: Hogan DJ, Berquó E, Costa HSM, editors. Population and environment in Brazil: Rio+10. Brasília: Comissão Nacional de População e Desenvolvimento/Belo Horizonte: Associação Brasileira de Estudos Populacionais/Campinas: Núcleo de Estudos Populacionais, Universidade Estadual de Campinas; 2002. p. 183-206.

30. Azevedo MM, Ricardo FP. Censo 2000 do IBGE revela contingente "indígena" pouco conhecido. São Paulo: Instituto Socioambiental; 2002.

31. Simões CCS. Perfis de saúde e de mortalidade no Brasil: uma análise de seus condicionantes em grupos populacionais específicos. Brasília: Organização Pan-Americana da Saúde; 2002.

32. Fundação Nacional de Saúde. Política nacional de atenção à saúde dos povos indígenas. 2a Ed. Brasília: Fundação Nacional de Saúde; 2002.

33. Garnelo L, Macedo G, Brandão LC. Os povos indígenas e a construção da política de saúde no Brasil. Brasília: Organização Pan-Americana da Saúde; 2003.

34. Lunardi R, Santos RV, Coimbra Jr. CEA. Morbidade hospitalar de indígenas Xavante, Mato Grosso, Brasil (2000-2002). Rev Bras Epidemiol 2007; 10:441-52.

35. Coimbra Jr. CEA, Garnelo L. Questões de saúde reprodutiva da mulher indígena no Brasil. In: Monteiro S, Sansone L, organizadores. Etnicidade na América Latina: um debate sobre raça, saúde e direitos reprodutivos. Rio de Janeiro: Editora Fiocruz; 2004. p. 153-73.

36. Wood JW. Fertility in anthropological populations. Annu Rev Anthropol 1990; 19:211-42.

37. Bongaarts J, Potter RG. Fertility, biology, and behavior: an analysis of the proximate determinants. New York: Academic Press; 1983.

38. Departamento de Identificação e Delimitação, Diretoria de Assuntos Fundiários, Fundação Nacional do Índio. Listagem de terras indígenas: relatório geral. Brasília: Fundação Nacional do Índio; 2004.

Submitted on $07 /$ Jan $/ 2011$

Final version resubmitted on 14/Apr/2011

Approved on 29/Jun/2011 